\title{
Research on the Top-Down Design of China's Economic Reform and National Governance Modernization
}

\author{
Jie Gao, Yunlong Ding \\ Harbin Institute of Technology, Harbin, China
}

\begin{abstract}
China's economy shifts from rapid growth stage into slower "new normal" stage. With growth and stability of the stage, China needs to gradually transfer from the exploration of "crossing the river by feeling the stones" and "bottom-up design", into the "top-down design" of reform and the whole promotion of system. The general objective proposed in the Third Plenary Session of 18th Congress of Communist Party of China is to improve and develop the socialist system with Chinese characteristics, and promote the modernization of national governance system and governance capacity. In the face of the economic downturn pressure of "new normal" and comprehensive reform needs, China needs to introduce a series of strategic planning and top-down design work, focus on economic reform and give play to its role as a driving force, make top-down design well and realize national governance modernization. In continuing to take economic development as the central task, it is essential to maintain an unswerving commitment to focusing on economic reform and governance modernization.
\end{abstract}

Keywords: GDP (gross domestic product), new normal, top-down design, economic reform, national governance modernization

When the world has come into the 21th century, there have been many major shifts in the global economic landscape. China's economy has kept a high growth rate. Even after the financial crisis of 2008, the impact is relatively small. In 2010, China's total GDP (gross domestic product) surpassed Japan, and China became the world's second largest economy. However, behind the rapid growth, there are all sorts of problems. China's economy has gradually into the deep water area and the period of transition. With fully aware of these problems, the new central government has stressed to reinterpret GDP and economic growth in perspective, deepen all-round reform, make top-down design well, and economic work should adapt to the "new normal" economic development.

\section{The Background and Meaning of "Top-Down Design", "New Normal", and National Governance Modernization}

"Top-down design" is a terminology of system engineering, network engineering. Its migration and introduction into the field of Chinese politics and the reform, is the enrichment and improvement of "scientific development". The Fifth Plenary Session of 17th CPC (Communist Party of China) National Congress and the

Corresponding author: Jie Gao, Ph.D. candidate, School of Management, Harbin Institute of Technology; research fields: public administration, governance, policy and management of science and technology. E-mail: littlehope@126.com.

Yunlong Ding, Ph.D., professor, School of Management, Harbin Institute of Technology; research fields: public administration, governance, policy and management of science and technology. E-mail: dingyunlong@hit.edu.cn. 
"Twelfth Five Year Plan" proposed to "pay more attention to the top-level design and overall planning", and deepen the reform comprehensively. China's economy shifts from rapid growth stage into slower "new normal" stage. With growth and stability of the stage, China needs to gradually transfer from the exploration of "crossing the river by feeling the stones" and "bottom-up design", into the "top-down design" of reform and the whole promotion of system (Gao \& Ding, 2015).

In November 2012, the new central government with Xi Jinping as general secretary steered the ship of the collective economic development and noticed the major change and potential influence of China's economy. At the end of 2013, the central made important judgment on the economic situation of "three period superimposed" (the speed shifting period of economic growth, the structural adjustment pains period, and the digestion period of stimulus policy), and it was the first time the central unified decision-making cognition: China's economy was shifting from the high speed to mid-high speed development period. On the first half of 2014, General Secretary Xi Jinping emphasized "Economic work should adapt to the new normal of economic development" in the Political Bureau of the Central Conference, and the investigation in Henan Province. In November 2014, at the APEC (Asia-Pacific Economic Cooperation) summit in Beijing, he explained the China's economy "new normal" had the speed change, structural optimization, and power conversion three characteristics. At the end of 2014, in the Central Economic Work Conference, he meticulously analyzed nine trends of changes of China's economy "new normal" (Wang, 2015).

The General Secretary of CPC Xi Jinping published an article entitled "Unifying the Thinking in the Spirit of the Third Plenary Session of 18th Central Committee of the CPC", and he explained the basic and specific meaning of the national governance system and governance capacity.

A country's national governance system and governance capacity represent a concentrated embodiment of that country's systems and its capacity to enforce those systems. China's national governance system can be understood as a full set of closely linked and coordinated national systems through which the country is governed under the leadership of the party. It consists of institutions, mechanisms, laws, and regulations with regard to economy, politics, culture, society, ecological progress, and party building. China's national governance capacity refers to our capacity to administer various social affairs through the application of national systems. This includes promoting reform, development, and stability, handling domestic affairs, foreign affairs, and national defense, and governing the party, the state, and the armed forces. A country's national governance system and governance capacity complement one another to form an organic whole. We say this because a sound governance system is essential for the improvement of governance capacity, while the improvement of governance capacity is a necessary precondition for fully exerting the effectiveness of a governance system.

He also points out, China's political stability, rapid economic growth, social harmony, and ethnic solidarity come in stark contrast to the continuous turmoil that has been seen in certain countries and regions of the world. This demonstrates that our national governance system and governance capacity are generally sound, and that they are geared to our national situation and to the needs of our national development (Xi, 2014).

At present, China's basic national condition remains unchanged: China is still in the primary stage of socialism, and will continue to be so for a considerable period of time to come. The ever-growing material and cultural needs of the people are still unable to be met by China's backward social production —which constitutes the principal problem in Chinese society at present-and China's international status as the largest developing country in the world has yet to change. These facts indicate that economic development is still the central task of the entire country. The reform of the economic system is the focus of all the efforts to deepen the all-round reform and the top-down design of China's economic reform is the important and key 
work in new normal stage. The general objective proposed in the Third Plenary Session of 18th Congress of Communist Party of China is to improve and develop the socialist system with Chinese characteristics, and promote the modernization of national governance system and governance capacity. In the face of the economic downturn pressure of "new normal" and comprehensive reform needs, China needs to focus on economic reform and give play to its role as a driving force, make top-down design well, and realize national governance modernization.

\section{The Interpretation of Top-Down Design of China's Economic Reform and National Governance Modernization}

\section{The Interpretation of China's Economy From the Multiple Aspects of GDP}

GDP is an important indicator to measure the economic condition of a country. Since the reform and opening-up, China has experienced 30 years' development, made full use of resources, labor force, and other advantages, introduced of advanced Western technology, carried out the policy of "bringing in" and "going out", and finally achieved a rapid economic growth.

As shown in Figure 1, in 1992-2011 years, despite of occasional fluctuations, Chinese GDP growth rate is still at an average annual growth rate of almost $10 \%$. But since 2012, the GDP growth rate has fell below $8 \%$, and has been in the range around $7 \%-8 \%$.

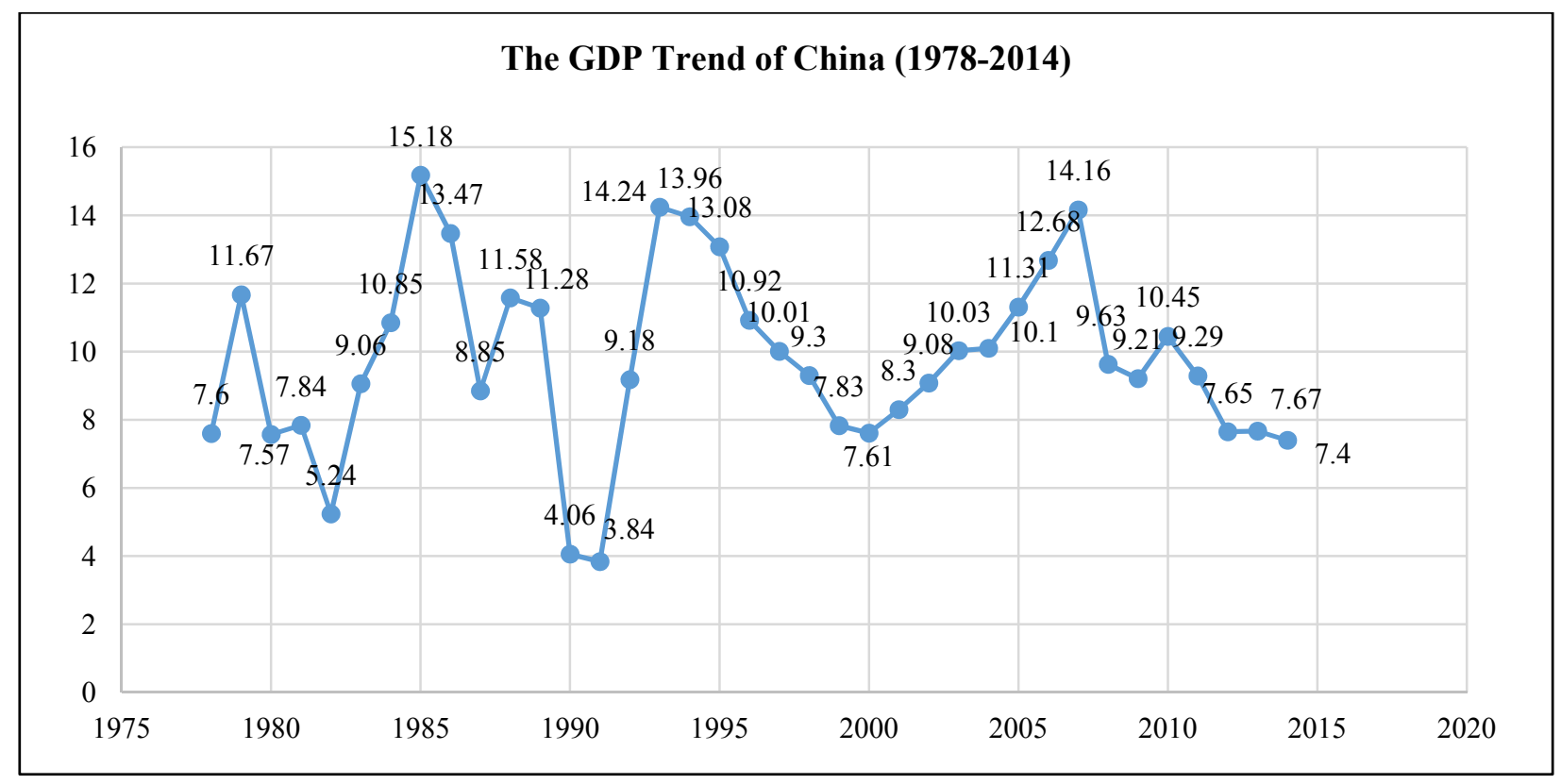

Figure 1. The GDP trend of China (1978-2014). Source: World Bank.

As shown in Table 1, the total GDP growth far exceeds the GDP per capita growth from 2004 to 2013. There is a saying, "guojin mintui (the state advances and the private sector retreats, or the government gets richer and the people get poorer)". This view is not comprehensive and not accurate. Given the rapid growth of GDP and lower GDP per capita, China has a large population, and will remain in the developing state for a long time. But after 2011 and 2012, the growth of per capita GDP is fast and stable in the "new normal" stage. The GDP and GDP per capita together are slow growing, and the gap between them is narrowing. 
Table 1

The GDP and GDP per Capita of China (2004-2013)

\begin{tabular}{llllll}
\hline Indicator & 2004 & 2005 & 2006 & 2007 & 2008 \\
\hline GDP per capita (yuan) & 12,400 & 14,259 & 16,602 & 20,337 & 23,912 \\
GDP (100 million yuan) & $160,714.4$ & $185,895.8$ & $217,656.6$ & $268,019.4$ & $316,751.7$ \\
\hline Indicator & 2009 & 2010 & 2011 & 2012 & 2013 \\
\hline GDP per capita (yuan) & 25,963 & 30,567 & 36,018 & 39,544 & 43,320 \\
GDP (100 million yuan) & $345,629.2$ & 408,903 & $484,123.5$ & 534,123 & $588,018.8$ \\
\hline
\end{tabular}

Note. Source: National Bureau of Statistics of PRC (People's Republic of China).

China's economy overtakes Japan in the second quarter of 2010 and becomes the world's second largest, and is growing at three times the pace of USA. In 2012, China's GDP growth is slowing down, and keeps low speed similar to USA. In these countries, the GDP growth rate of China is always the largest. After 2011, both China and India's growth rate start to slow down, but the slowing trend of China is relatively more stable.

In comparison with some low income, lower middle income, upper middle income, and high income countries, GDP per capita of China still belongs to the middle and lower levels, which determines that China will remain developing state in a long period. Although there are differences in the GDP based on PPP (purchasing power parity) valuation ranking table and data from different organizations and groups, the GDP based on the PPP evaluation of China surpasses USA for the first time and tops the world's most in 2014, and this trend will continue (see Tables 2-4). PPP is another GDP calculation method, but also can show trend of the total and rate of China GDP growth in a certain extent.

Figure 2 shows the three industrial added value of China’s GDP (¥), of which third industrial contribution in 2012 (also known as the "new normal" stage) beyond the second industrial for the first time. Under the China economy "new normal", China economic structure is in the gradual transition and adjustment. While in active speed reduction economic growth, China creates space for transfer mode, adjusts the structure, and promotes reform. There is a certain amount of improvement in the "new normal".

Table 2

GDP Based on PPP Valuation Ranking Table and Data From the International Monetary Fund (2014)

\begin{tabular}{|c|c|c|c|c|c|}
\hline Rank & Country & GDP (billions of US\$) & Rank & Country & GDP (billions of US\$) \\
\hline & World & $108,036.50$ & 5 & Germany & $3,721.60$ \\
\hline & European Union & $18,526.50$ & 6 & Russia & $3,564.50$ \\
\hline 1 & China & $17,617.30$ & 7 & Brazil & $3,263.80$ \\
\hline 2 & United States & $17,418.90$ & 8 & Indonesia & $2,676.10$ \\
\hline 3 & & 2,006 & 9 & & $2,580.80$ \\
\hline & India & & & France & \\
\hline 4 & Japan & $4,750.80$ & 10 & $\begin{array}{l}\text { United Kingdom } \\
\text { Units }\end{array}$ & $2,548.90$ \\
\hline
\end{tabular}


Table 3

GDP Based on PPP Valuation Ranking Table and Data From the World Bank (2005-2014)

\begin{tabular}{|c|c|c|c|c|c|c|c|}
\hline Rank & Country & GDP (billions of US\$) & Year & Rank & Country & GDP (billions of US\$) & Year \\
\hline & World & 108,464 & 2014 & 5 & Russia & 3,745 & 2014 \\
\hline & European Union & 18,423 & 2014 & 6 & Germany & 3,690 & 2014 \\
\hline 1 & China & 18,031 & 2014 & 7 & Brazil & 3,264 & 2014 \\
\hline 2 & $\overline{\text { United States }}$ & 17,419 & 2014 & 8 & Indonesia & 2,676 & 2014 \\
\hline 3 & India & 7,996 & 2014 & 9 & France & 2,572 & 2014 \\
\hline 4 & Japan & 4,631 & 2014 & 10 & $\begin{array}{l}\text { United Kingdom } \\
\text { Und }\end{array}$ & 2,525 & 2014 \\
\hline
\end{tabular}

Table 4

GDP Based on PPP Valuation Ranking Table and Data From the CIA (Central Intelligence Agency) World Factbook (1993-2014)

\begin{tabular}{|c|c|c|c|c|c|c|c|}
\hline Rank & Country & GDP (billions of US\$) & Year & Rank & Country & GDP (billions of US\$) & Year \\
\hline \multirow{3}{*}{1} & World & 107,500 & 2014 & 5 & Germany & 3,621 & 2014 \\
\hline & China & 17,630 & 2014 & 6 & Russia & 3,568 & 2014 \\
\hline & European Union & 17,610 & 2014 & 7 & Brazil & 3,473 & 2014 \\
\hline 2 & United States & 17,460 & 2014 & 8 & France & 2,587 & 2014 \\
\hline 3 & & 7,277 & 2014 & 9 & & 2,554 & 2014 \\
\hline 4 & $\begin{array}{c}\text { India } \\
\text { Japan }\end{array}$ & 4,807 & 2014 & 10 & $\begin{array}{l}\text { Indonesia } \\
\text { United Kingdom }\end{array}$ & 2,435 & 2014 \\
\hline
\end{tabular}

Notes. Economic and political unions that are not countries, and are therefore not ranked. Source: International Monetary Fund (IMF), World Bank, and CIA World Factbook.

With more than 30 years of reform and opening-up, the "population burden" in agriculture and state-owned enterprise sector makes successful transition to the "demographic dividend" which promotes rapid economic growth. This is one of the important sources of China's GDP growth (Simon, 2000; Cai, 2004; P. Zhang, Liu, X. Zhang, Yuan, \& Wang, 2007). From the demographic dividend to the human resources dividend, the ability supporting the rapid growth of China's GDP gradually upgrades. The development of human resources will become a long-term support for the future development of China's GDP (Guo, 2015). 


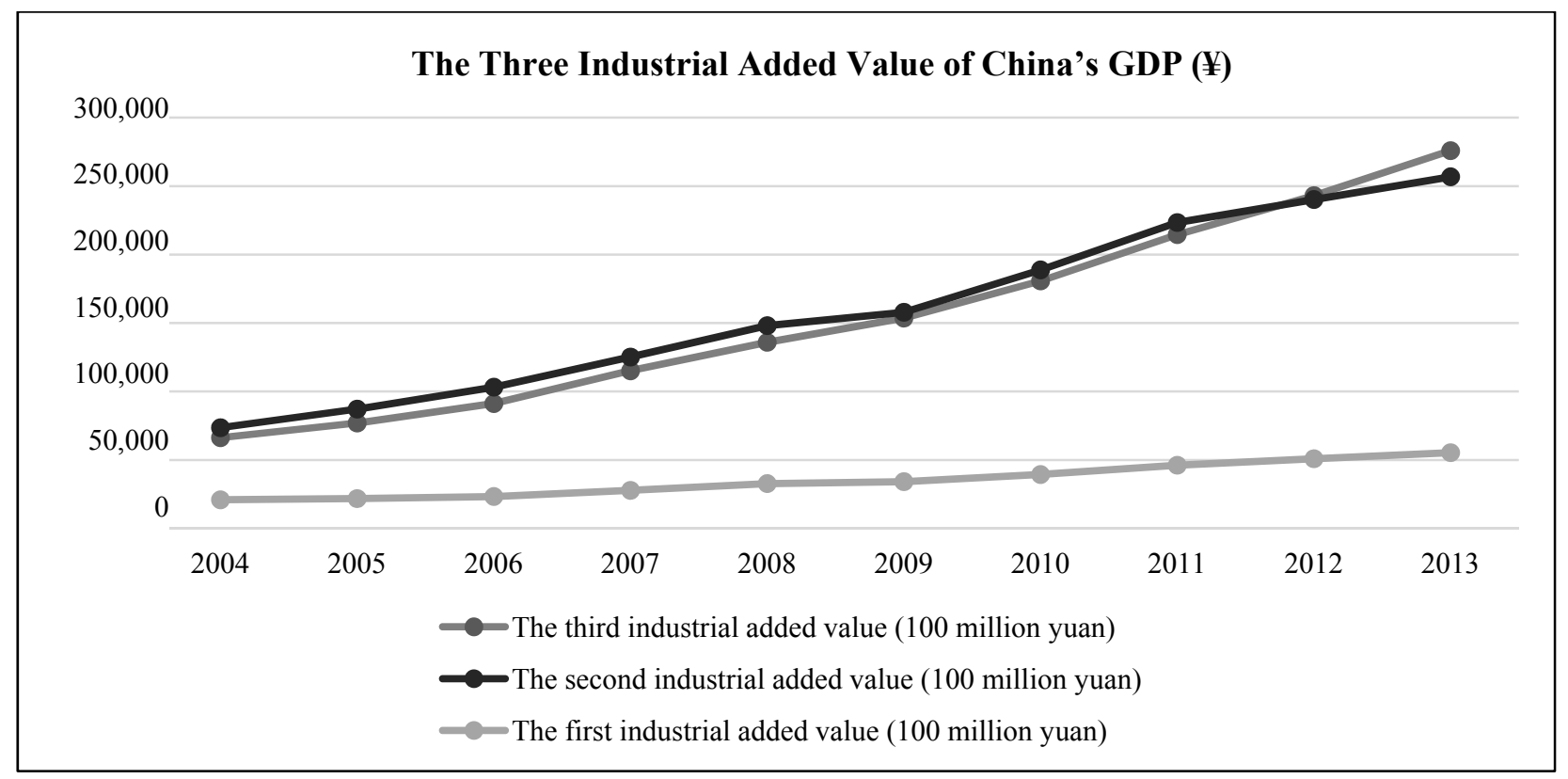

Figure 2. The three industrial added value of China’s GDP (¥). Source: World Bank.

\section{The Top-Down Design and Some Measures of China's Economic Reform and National Governance Modernization}

The reform of the economic system is the key and focus of all the efforts to deepen the all-round reform and governance modernization. To carry out economic reform and governance needs to make the top-level design, overall planning well and implement layer by layer.

From the report and spirit of the Third Plenary Session of 18th Central Committee of the CPC, the first step of economic reform roadmap is to further free our minds, further release and develop productive forces, and further unleash and boost the vigor of our society.

China's economic system is one with public ownership serving as its main body but allowing for the development of all types of ownership. Both public and non-public ownership are key components of China's socialist market economy. One of the key works of economic reform roadmap is to uphold and improve the basic economic system: complete the property rights protection system, and actively develop a diversified ownership economy; push for a modern system for state-owned enterprises, and support the healthy development of the non-public economy, which will play an important role in fostering growth, promoting innovation, expanding employment, and increasing tax revenues. All these measures are the specific performance of upholding and improving the basic economic system.

The other key work of economic reform roadmap is to accelerate the improvement of modern market system. Make market rules that are fair, open, and transparent, and perfect a mechanism where prices are determined by the market; form a construction-land market that unifies urban and rural areas; improve financial markets and further open up the financial industry; deepen science and technology system reform. All these measures are efforts, which are to be made to build a market system that is uniform but open, orderly, and competitive.

To make the top-down design well, and in continuing to orient our economic reform toward the socialist market economy, an important work and governance is to balance the relationship between the government and 
the market, so that the market is able to play the decisive role in the allocation of resources while the government is able to exert its own role more effectively. Accelerating the transformation of government functions is necessary. Chinese government needs to improve macroeconomic regulation and control, and perform government duties comprehensively and correctly; streamline government structure and actively and steadily carry out reform that merges ministries that have overlapping functions.

To realize governance modernization, deepening fiscal and taxation system reform is another one of the key works and important guarantees: improve the budgetary system and establish a standard and reasonable debt management system for central and local governments and a risk-alert system; improve the taxation system, and perfect the local taxation base by gradually raising the share of direct taxation; establish a system in which the government's administrative authority is commensurate with its spending responsibility and so on. All these measures are the specific performance of deepening fiscal and taxation system reform and modernize national governance.

China's economic boom benefits from the reform and opening-up policy. Building an open economy new system and promoting further opening-up is helpful to the top-down design work and governance modernization: widen investment access and speeding up the construction of free-trade zones, with adherence to the rules of world trade system and insistence on bilateral, multilateral and regional cooperation; further opening-up inland and border areas, and establishing financial institutions focusing on development to accelerate infrastructural connections among neighboring countries and regions, such as Asian Infrastructure Investment Bank, New Development Bank, and so on.

The government has already introduced a series of strategic planning and top-down design work. The release of the Vision and Actions on Jointly Building Silk Road Economic Belt and 21st-Century Maritime Silk Road, the establishment of AIIB (Asian Infrastructure Investment Bank), BRICS (Brazil, Russia, India, China, and South Africa) Bank, new FTA (Free Trade Agreement) and Yangtze River economic belt, the integration Beijing, Tianjin, and Hebei, the revitalization of the northeast and so on. These are the specific performances and measures to achieve the goal of economic reform and national governance modernization.

\section{Final Thoughts}

After the rapid GDP growth rate (>10\%) that defined the first decade of the 21st century, China's GDP growth rate for the first time was less than $10 \%$ in 2011. In 2012, the rate was below $8 \%$ and approached lowest rate in the 21 st century. The rate has been around $7 \%-8 \%$ these three years and there is a trend of economic downturn. In difficult times, policymakers realize that although the economic growth slows down, its rate is still at a reasonable interval, and then continue to take a diametrically opposite approach through analysis and research, the most important challenge and problem to the current China's economy is the "three periods superimposed": (1) growth rate shift period is decided by the objective laws of economic development institute; (2) structural adjustment pains period is the active choice of speeding up the transformation of economic development mode; and (3) stimulus policy digestion period is a necessary stage to resolve the deep-seated contradictions accumulated over the years.

The 2013 world economy yellow book predicts that the slow growth would be the new norm of global economic growth (Wang \& Zhang, 2013). The mid-high growth of 7\%-8\% is a reasonable reflection of the characteristics of the growth rate of China's GDP and an irreversible stable development state (Guo, 2015). Throughout the annual GDP growth rate in the Twelfth Five-Year Plan, in addition to Tibet, the economic 
growth rate is generally showing a unilateral downward trend, reaching the lowest value in 2015. This trend clearly reflects the economy shifts from high speed to mid-high speed, but also shows that the current slowdown is further confirming (Wang, 2015). In the coming period, China's economy will inevitably face the pressure of economic slowdown, which is a feature of the "three periods superimposed" of the new normal. In the face of pressure, we need to maintain sufficient confidence and strategic concentration to reform (Liu, 2014).

Many of the institutional and structural barriers that are constraining scientific development are found in our economic system. This indicates that our tasks in economic reform are far from being fulfilled, and that the potential of economic reform has yet to be fully unleashed. Therefore, in continuing to take economic development as our central task, it is essential that we maintain an unswerving commitment to focusing on economic reform. The economic base determines the superstructure. Economic reforms are able to play a major role in influencing and guiding reforms in other areas. That is to say, the progression of major economic reform determines the progression of structural reforms in many other areas, with a single step having the potential to affect the overall situation (Xi, 2014).

Economic development of China is in the mid-high speed growth, and transferring from the exploration of "feeling stone to cross a river" and "bottom-up design", into the "top-down design" of reform and promotion of national governance modernization. It means that Chinese socialism will make a solid foundation and promotion to the overall layout of "five in one" (economic construction, political construction, cultural construction, social construction, and ecological civilization construction).

\section{Conclusions}

The purpose of this paper attempts to start from the policy-making and economic development process of "new normal", "top-down design" and deepening the reform policy comprehensively, and through analysis of GDP's different level and the specification and interpretation from the angle of "top-down design" and governance modernization, to prove that China's economy "new normal" is neither the end of "Chinese miracles", nor "Chinese economic recession or deflation", and it is a period of transition and shift of China's economy growth.

Compared with GDP trends of the G7 (Group of Seven), the BRICS, and other countries, China's GDP growth rate is relatively high and fast. Because of the relatively independent economic, monetary policy, and the unique Chinese plus model of economic development, with small effects of the economic cycle and the exchange rate by America leading, China has always maintained a high speed of economic growth for nearly 20 years. While in active speed reduction economic growth, China creates space for transfer mode, adjusts the structure, and promotes reform. There is a certain amount of improvement in the "new normal".

From the perspective of originality/value, the paper emphasizes on index analysis of the "new normal", "top-down design", governance modernization, and other related areas. With respect to both developed and developing countries, China should give full play to their own advantages to achieve development and adhere to socialism with Chinese characteristics rigidly. The results may help to understand the Chinese GDP, "top-down design", governance modernization, and to have further understanding of "new normal" of China's economy.

The paper is only limited to official data and government documents, not from the nongovernmental, the private, and corporate aspects. The study focuses on data analysis and contrast of GDP, and interpretation of 
government documents. The future research focus needs from the perspectives of multi-level data and phenomenon reflect the economic to discuss China's economy and governance.

\section{References}

Cai, F. (2004). Demographic transition, demographic dividend and sustainability of economic growth. Population Research, 28(2), $2-9$.

Gao, J., \& Ding, Y. L. (2015). Visualization analysis of "top-down design of reform" research hotspot and frontier. Reform \& Opening, 416(11), 46-48.

Guo, X. H. (2015). Research on the mid-high growth of China's GDP in the background of economic "new normal". Social Science in Hubei, 2, 88-92.

Liu, Y. C. (2014, June 12). Maintain the concentration adapt and regulate the "new normal". People's Daily, p. 10.

Simon, J. (2000). Has population growth been a drag on economic growth? The revolution of development economics. Shanghai: Shanghai Sanlian Press.

Wang, J. (2015, March 2). China's economy: New normal big logic. Outlook Weekly, 9, 8.

Wang, L. L., \& Zhang, Y. Y. (2013). 2013 world economic situation and forecast. Beijing: Social Science Literature Press.

Wang, Y. (2015). The GDP change in the "new normal". Zhejiang Economy, 557(3), 37.

Xi, J. P. (2014, January 1). Unifying the thinking in the spirit of the Third Plenary Session of 18th Central Committee of the CPC. Qiushi, 1, 3-6.

Zhang, P., Liu, X. H., Zhang, X. J., Yuan, F. H., \& Wang, H. J. (2007). Labor supply effect and the transition of China's economic growth path. Economic Research Journal, 42(10), 4-16. 